\title{
Tourism, an Underestimated Driving Force for the Creative Economy
}

\section{Abstract}

Greg Richards

This study examines the relationship between tourism and the creative economy. An increasing number of countries, regions and cities are developing policies to link tourism and creativity to economic growth and support cultural and creative activities. As a result, different models of "creative tourism" have emerged. Case studies of creative tourism development are described from different parts of the world, and their effects are examined. Particular attention is paid to the role of knowledge, which the Organisation for Economic Cooperation and Development (OECD) sees as central to the development of creative tourism. Because tourism can be a tool for the circulation of knowledge and creation of links between creative individuals, it can arguably support the development of the creative economy.

Keywords: Creative economy; Creative tourism; Creative policies; Tourism development.

\section{Resumo}

\section{Turismo, uma força motriz subestimada para a economia criativa}

Este estudo analisa a relação entre o turismo e a economia criativa. Um número crescente de países, regiões e cidades vem desenvolvendo políticas para vincular o turismo e a criatividade ao crescimento econômico e apoiar atividades culturais e criativas. Como resultado, diferentes modelos de "turismo criativo" surgiram. Estudos de caso do desenvolvimento do turismo criativo são descritos em diferentes partes do mundo, e seus efeitos são analisados. Uma atenção especial é dada ao papel do conhecimento, que a Organização para Cooperação e Desenvolvimento Econômico (OCDE) considera primordial para o desenvolvimento do turismo criativo. Como o turismo pode ser uma ferramenta para a circulação de conhecimento e criação de vínculos entre indivíduos criativos, ele pode sustentar o desenvolvimento da economia criativa.

Palavras-chave: Economia criativa; Turismo criativo; Políticas criativas; Desenvolvimento do turismo.

\section{Resumen}

\section{Turismo, una fuerza motriz subestimada en la economía creativa}

El presente estudio analiza la relación entre el turismo y la economía creativa. Cada vez más países, regiones y ciudades están desarrollando políticas para vincular el turismo y la creatividad con el crecimiento económico y para apoyar las actividades culturales y creativas. Como resultado, han surgido diferentes modelos de "turismo creativo". Los estudios de caso sobre el desarrollo del turismo creativo se realizan en diferentes partes del mundo y se analizan sus efectos. Se pone atención especial al papel del conocimiento, que la Organización para la Cooperación y el Desarrollo Económicos (OCDE) considera fundamental para el desarrollo del turismo creativo. Dado que el turismo puede ser una herramienta para la difusión del conocimiento y para establecer vínculos entre individuos creativos, también puede sostener el desarrollo de la economía creativa.

Palabras clave: Economía creativa; Turismo creativo; Políticas creativas; Desarrollo del turismo.

a. PhD in Geography from University College, London, United Kigdom. Professor of Placemaking and Events at Breda University, Breda, Netherlands. E-mail: richards.g@buas.nl 


\section{INTRODUCTION}

Tourism is often quoted as being one of the world's largest and fastest growing industries (UNWTO, 2016), so its relationship with the creative economy is not surprising. Tourists are increasingly seeking engaging experiences in the places they visit, and culture and creativity provide the narratives and content for many contemporary tourism products. A recent report by the UNWTO (2018) indicated that around $40 \%$ of international tourism, or about 480 million trips a year, include cultural activities. The report also notes a shift from visits to tangible heritage (museums, monuments etc.) towards intangible heritage (e.g. festivals, art performances) and creative experiences.

Such trends are strengthening the relationship between tourism and creative economy, as outlined by a recent report from the Organisation for Economic Cooperation and Development (OECD) on Tourism and the Creative Economy (2014). In the context of the OECD study, the creative economy was defined as comprising "knowledge-based creative activities that link producers, consumers and places by utilising technology, talent or skill to generate meaningful intangible cultural products, creative content and experiences." Tourists, just as other mobile groups, are attracted by the creativity, vibrancy and innovation that are supported by the creative economy (Richards \& Carvalho Marques, 2015). The links between the creative economy and tourism range from the food cultures and gastronomy of the destination to cultural events of music, fashion and design, all of which are important attractors. This includes the general creative "atmosphere" or "scene" developed by the creative economy or more specific creative industries and activities.

Recently, a significant growth in "film induced tourism" has been observed in areas where popular movies were filmed. The film Lost in Thailand earned over one billion RMB at the box office in China, attracting audiences of over 30 million. There was a 93\% increase in Chinese tourists to Thailand after the film's release. Lost in Thailand II is now being filmed, and other countries have also sought to cash in on the Chinese film tourism market with the shooting of Lost in Hong Kong and Lost in India.

Linkages between tourism and the creative economy can generate many effects that go far beyond increasing demand for tourism experiences (Organization for Economic Co-operation and Development, 2014). These include:

- Increasing tourism demand and/or changing tourist profiles by generating new and engaging tourist experiences;

- Image building through the improvement of the marketing and design of places;

- Developing "soft infrastructure," such as small-scale creative businesses, creative spaces, courses, experiences, cafes and restaurants that function as nodes in creative networks, allowing producers and consumers to interact;

- Atmosphere creation in order to make places more attractive to creative workers, tourists and residents; 
- Attracting creative talent by increasing the quality of life and the equality of opportunity in both tourism and creative industries;

- Stimulating innovation by adding creative impulses and new technology to tourism development and challenging the creative industries to find new ways to manage tourism and improve tourism business operations;

- Driving exports through products that link creative content, places and culture in order to increase general levels of interest in local creativity and stimulate tourist visitation;

- Clustering and network building to help establish places as nodes in creative networks, stimulating both business and leisure travel and bringing creative activities together in permanent (clusters) or temporary nodes (events);

- Knowledge and skill development as a result of increasing contacts between professionals from creative and tourism industries, between producers and consumers and between consumers and residents.

More attention is now being paid to the links between creativity and tourism, both by cultural and tourism policy makers. For example, the recent Siam Reap Declaration on Cultural Tourism (World Tourism Organization, 2015) underlined the need to "Promote stronger links between tourism, living cultures and creative industries."

\section{POLICY DEVELOPMENT}

\section{The increasing}

Increasing attention to creativity and tourism reflects the growing importance of the creative economy in recent years. In addition to the many countries stimulating the creative economy as a source of income and jobs, the spread of creative economy approaches is being stimulated by international bodies such as OECD and UNCTAD. UNCTAD has produced international overviews on the creative economy, as well as national reviews. The most recent national report covers the Republic of Korea (United Nations Conference on Trade and Development, 2017), which is a particularly interesting example of the integration between creative industries, content industries and tourism. Many emerging economies are now investigating the potential of the links between the creative economy and tourism. Creative economy policies in developing countries are often connected with other development priorities, such as poverty alleviation, cultural heritage protection, social inclusion, and tourism, since creative products can be additional attractions in tourist destinations.

The shift of creative economy approaches to emerging economies raises questions about the appropriateness of creative policy transfer. As Fahmi, McCann and Koster (2017) argue, emerging economies may find it difficult to adopt the original (western) concept of creative economy, because of distinct motivations, differences in the economic structure and values. But creative 
development is also highly attractive because of the relatively mobile nature of creativity. The growth in the creative economy and new technologies have made creative content available almost everywhere. Thus, it is important for creative producers, and particularly the countries or regions they are based in, to develop a link with the place. This can increase the distinctiveness of creative products, helping them to compete internationally as well as locally. In tourism terms, a specific link with the place gives a unique identity to creative products and gives people a reason to visit that place. Embedding creativity in place is therefore an important dimension of both creative economy and tourism policy.

In this sense, there are many opportunities for emerging economies in the growing creative sector of tourism. Many developing countries are relatively poor in high profile tangible heritage (such as Unesco World Heritage Sites), but rich in intangible heritage in the form of traditional practices and knowledge, for example.

There is a noticeable shift towards intangible content as the major product shared by tourism and the creative industries. This provides opportunities for the development of creative tourism and experiences by cultural and creative organisations. It also means that tourism organisations will have to develop a greater role in creative content production and distribution. This, in turn, requires the deployment of more creative skills within tourism organisations.

Creative innovations in tourism will also require the re-making of the travel system itself, shifting from a traditional value chain towards a more extensive and diffuse "value web" that not only includes travel suppliers, but also consumers, residents and other non-travel actors in a process of tourist experience co-creation.

This has a number of important policy implications according to the OECD (2014), including:

- Policies should focus on knowledge as a primary driver of value creation;

- Policies should bring producers and consumers together in order to cocreate value;

- New technologies provide the essential linkages between producers, consumers and places;

- The creative industries are largely based on intangible content, which generates new policy challenges compared with tangible culture;

- To fully exploit the added value potential of the creative industries, there needs to be more integration and convergence between industries and sectors.

These changes also imply new roles for the stakeholders in the creative tourism system, especially the public sector. Public authorities have an enabling role to play in developing creative tourism, including supporting SMEs, networks and cluster development. The private sector is leading the development of interesting, engaging creative content to attract visitors - tourism organisations need to be actively involved. The collaboration between tourism and creative industries implies knowledge and capacity development to achieve mutual benefits. 
A good example of this is the way public authorities are developing "smart tourism" initiatives through the application of creative technology solutions. In South Korea, for example, "IT-based creative tourism" is being promoted through programmes such as the Creative Tourism Contest Project, which gives development funding to creative tourism projects, particularly those concerning the application of new technologies (OECD, 2014). The "Blinking Seoul" project combines a range of smart applications to allow foreign visitors to navigate around the city in their own language and gather detailed background information on neighbourhoods and attractions in the city. This is one example of how cities are using the big data that they possess to give richer information about culture and creativity to visitors (Shim, Lee, \& Yoo, 2016).

\section{THE TRANSITION TO CREATIVE TOURISM}

From a consumer perspective, new opportunities also emerge from the transition from traditional cultural tourism to creative tourism. As consumers demand more engaging interactive cultural experiences, conventional cultural tourism is increasing due to "creative tourism". Richards and Raymond (2000, p. 18) first defined this as:

Tourism which offers visitors the opportunity to develop their creative potential through active participation in courses and learning experiences, which are characteristic of the holiday destination where they are taken.

According to the definition of creative economy adopted by the OECD (see above), creative tourism might be redefined as "knowledge-based tourism activities that link producers, consumers and places by utilising technology, talent or skill to generate meaningful intangible cultural products, creative content and experiences that are characteristic of the destination." This application of creative skills to the development of tourism experiences can take many forms, including the development of creative courses and workshops, creative events, encounters with creative producers, and the development of creative spaces such as design hotels.

The linkages being created between producers and consumers of creative tourism are producing a shift towards the "co-creation" of experiences, in which skills and knowledge are transferred between local hosts and their visitors (Author). This also affects the traditional power relations in tourism, in which the host serves the needs of the tourist. In creative tourism the exchange is more equal, because both host and guest are contributing skills and knowledge to the creative process.

Creative tourism also emphasises the relational aspects of tourism. Authenticity is no longer defined solely by the culture encountered in museums, but increasingly relies on the "local" culture and creativity. The "live like a local" trend is extending to different areas of the world, and it is introducing tourists to a myriad of different lifestyles. The creative industries are particularly important in providing the kind of scenes that are attractive to people who live permanently in an area as well as different types of "temporary citizens" or mobile consumers (Author). 


\section{CASE STUDIES OF CREATIVE TOURISM DEVELOPMENT}

Creative tourism has evolved into many different forms, influenced by local creative resources and lifestyles. The international Creative Tourism Network (www.creativetourismnetwork.org) has member cities and regions spread across the world, all of which are developing their own style of creative tourism. As well as the case studies available from the CTN website, the examples below illustrate the ways in which the creative economy and tourism are becoming increasingly integrated through creative tourism development.

\section{Brazil}

Porto Alegre, in southern Brazil, has developed 40 different creative workshops and experiences, available to residents and visitors. A mapping exercise was created to identify potential creative tourism experiences. The themes range from crafts, fandango, preparing and drinking mate to the traditional churrasco or barbeque of the region. The objective is the interaction of the tourist with these experiences, by learning traditional dances or preparing traditional food, for example. Porto Alegre has been sharing its experience with many other destinations in Brazil, including Paraíba and Rio Grande do Norte, in northern Brazil, and Paraná.

In Recife, Pernambuco, many different creative tourism experiences are emerging thanks to the activities of the local creative sector. These include the "Playtown" project, which allows residents and visitors to interact with creative artifacts in the historic centre of the city (Marques \& Borba, 2017). The objects placed in public space will be devised by the participants and later developed by specialised technology companies (http://www.playtownrec.com.br/playtown/).

One of the projects highlighted in a recent conference on creative tourism held in Recife was Bomba do Hemetério, a neighbourhood where local cultural groups involve visitors in their creative activities, such as Carnival performances. Study by Alan Jones Santos do Nascimento (2014) found that this project has brought significant benefits. Around $80 \%$ of businesses in the area showed improvements in trade, while $37.5 \%$ reported increased profitability and $25 \%$ had increased customer flows. Many residents have participated in professional training through the programme, and $70 \%$ of residents felt that tourist itineraries had improved.

\section{Indonesia}

Since Indonesia created the Tourism and Creative Economy Ministry in 2011 there has been a growing relationship between these two sectors. The immense cultural diversity of the country provides a rich source of creative products and experiences of interest to tourists and global export markets. Creativity can add value to existing cultural attractions by developing creative production and preserving cultural values (Fahmi, 2014). With the combination of tourism and creativity, traditional cultural activities are transformed into creative industries.

One of the areas in which pilot projects on creative tourism have been established is the popular tourist destination of Bali. Study by Blapp and Mitas (2018) analysed the effect of such programmes on villages in Bali and found many positive synergies, including: 
1) Intangibility of creative tourism at low financial resources; preservation of

2) Preserving cultural heritage through creative learning experiences;

3) More equal power distribution between hosts and guests through creative tourism;

4) More enthusiasm of locals to share their culture through creative tourism;

5) Creative tourism involving locals without English knowledge.

Characteristic experiences occur in situ and require little investment. This activity also limits numbers and allows tourists to explore the location. This direct interaction places the location in a position of power, which can establish the direction of tourism development.

However, the researchers also noted that reliance on intangible heritage widespread among villages in the same region can be a challenge for differentiation and marketing of villages. Blapp and Mitas recommend the development of a unique aspect, rather than relying on experiences such as rice field trekking, which is present in almost every village.

\section{Thailand}

Thailand has been spearheading the development of creative tourism as a way of adding value to tourism experiences and supporting local creative development. The creative tourism programme run by the Designated Areas for Sustainable Tourism Administration (Dasta) has developed a network of villages that provide creative experiences for visitors. These experiences are often based on traditional arts and crafts, with the application of contemporary creativity (Wisansing, 2015).

One of the important aspects of Thailand's creative tourism programme is the development of relationships between visitors, creators and residents. These encounters are a means of exchanging values, knowledge and skills that can increase the creativity of all involved. Such relational models of creative tourism also support Thailand's drive towards "high value tourism" because the personalised nature of the creative experience is worth much more than the packaged experiences offered to mass tourists.

\section{The creative use of global networks}

The small Dutch city of 's-Hertogenbosch (Den Bosch) made extensive use of the creative industries, in 2016, in its programme of celebrations for the 500th anniversary of the death of the painter Hieronymus Bosch. This event aims to attract large numbers of tourists and to strengthen the creative and cultural fabric of the city by bringing Bosch to life, using his artistic legacy as a creative inspiration for the future. The interesting challenge for Den Bosch is that it does not have any of Bosch's works, as his remaining paintings are scattered in museums across the world. The city, therefore, has to develop a creative tourism product based entirely on intangible assets, including the creativity inspired by Bosch's work and the storytelling potential of his birthplace (Marques, 2013). 
In order to create global leverage, the city formed a network of Bosch Cities which included all the cities with works by Bosch. It then mounted a Research and Restoration Project to generate new knowledge about Bosch's work and restore his 25 or so surviving paintings. To participate in the project (and have their paintings restored for free), all the other cities needed to do was to lend their paintings to Den Bosch in 2016.This enabled Den Bosch to secure sufficient paintings to mount the largest ever exhibition of his work. The exhibition attracted around 400,000 visitors to the city, generating an economic impact twenty times greater than the city's investment in the exhibition.

By linking tourism and the creative industries, the city has overcome limitations in the supply of cultural heritage resources, developed its creative capacity, forged international networks to gather creative resources and focus visitor attention, and engaged citizens through the development of grassroots creativity. A city that was previously reliant on the heritage of the past has creatively linked itself to new sectors, such as gaming and design, to engage new visitor markets and extend its product portfolio.

\section{CONCLUSIONS}

The convergence of tourism and the creative economy provides opportunities for places to develop economic, cultural and social resources. Creative tourism offers a new model that can supplement existing forms of conventional or mass tourism and increase the linkages between visitors and residents and between tourism and creative sectors. A growing range of projects, networks and events related to tourism and creativity provide new models for maximising the beneficial effects of these linkages.

As creative tourism develops, one result of the creative spirit that drives such projects is an increasing diversity of applications and models. The original idea of creative tourism as a more formal transfer of knowledge via workshops and classes has gradually broadened into a vast range of different types of educational, experiential and creative encounters between tourists and locals. As the examples analysed in this study show, creativity has been applied to tourism at many different scales, from community-based projects in small villages to the creative development of smaller and larger cities. This also underlines the difficulty in developing creativity through top-down models. The most successful projects seem to be those that recognise and harness endogenous creativity and resources.

\section{REFERENCES}

Blapp, M., \& Mitas, O. (2018). Creative tourism in Balinese rural communities. Current Issues in Tourism, 21(11), 1285-1311.

Fahmi, F. Z. (2014, July 8). Promoting the creative economy. Retrieved from https://bit.ly/2UaAatl Fahmi, F. Z., McCann, P., \& Koster, S. (2017). Creative economy policy in developing countries: the case of Indonesia. Urban Studies, 54(6), 1367-1384.

Marques, L. (2013). Constructing social landscape through events: the global project of 's-Hertogenbosch. In G. Richards, M. Brito, \& Linda Wilks (Eds.), Exploring the Social Impacts of Events (pp. 84-94). London, GL: Routledge. 
Marques, L., \& Borba, C. (2017). Co-creating the city: digital technology and creative tourism. Tourism Management Perspectives, 24, 86-93.

Nascimento, A. J. S. (2014). Polo cultural da bomba do hemetério: um olhar sobre o programa bombando cidadania. Pesquisa de Bacharelado, Centro Universitário Maurício de Nassau, Siqueira Campos.

Organization for Economic Co-operation and Development (OECD). (2014). Tourism and the Creative Economy. Paris: OECD Publishing.

Richards, G., \& Raymond, C. (2000). Creative tourism. ATLAS News, (23), 16-20. Retrieved from https://bit.ly/2KsvFKX

Shim, B., Lee, H., \& Yoo, D. (2016). Development of Customized Trip Navigation System Using Open Government Data. Journal of Internet Computing and Services, 17, 15-21.

United Nations Conference on Trade and Development (UNCTAD). (2017). Strengthening the creative industries for development in the Republic of Korea. Geneva, GE: UNCTAD.

Wisansing, J. (2015). Redesign tourism. Bangkok, BM: Dasta.

World Tourism Organization (UNWTO). (2015). Siem Reap Declaration on Tourism and Culture Building a New Partnership Model. Madrid, MD: UNWTO. Retrieved from https://bit.ly/2Uc0mna

World Tourism Organization (UNWTO). (2016). Facts \& Figures edition page. Madrid, MD: UNWTO. Retrieved from https://bit.ly/2KpjFKj

World Tourism Organization (UNWTO). (2018). Tourism and Culture Synergies. Madrid, MD: UNWTO.

\section{CONTRIBUTIONS}

Greg Richards: Defined the research problem and objectives; developed the theoretical proposition; performed the literature review and theoretical foundation; chose the methodological procedures; carried out data collection, data analysis, prepared the tables, graphs and figures, performed the calculations and projections; wrote and formatted the manuscript to the RTA rules. 